\title{
On-farm investigation of local chicken biodiversity and performance potentials in rural areas of Jordan
}

\author{
A.Abdelqader ${ }^{1}$, C.B.A. Wollny ${ }^{2} \mathcal{E}$ M. Gauly ${ }^{3}$ \\ ${ }^{1}$ Animal Breeding and Husbandry in the Tropics and Subtropics, Georg August University Göttingen, \\ Kellnerweg 6, 37077 Goettingen, Germany \\ ${ }^{2}$ International Livestock Research Institute (ILRI), P.O. Box 5689, Addis Ababa, Ethiopia \\ ${ }^{3}$ Institute of Animal Breeding and Genetics, Georg August University Göttingen, \\ Albrecht Thaer Weg 3, 37075 Goettingen, Germany
}

\section{Summary}

On-farm surveys were conducted to investigate the biodiversity of local chickens and their performance potential. The study was carried out in rural areas of northern Jordan. A sample of 846 adult local chickens was phenotypically characterized based on morphology, feather colors, comb shape and performance. Body measurements for cluster analyses were recorded on 460 adult females. The most predominant chicken type was the Jordan Baladi (67.3\%) followed by the Pakistani (27.7\%) and the Brahma (5\%). Cluster analyses showed that the three populations are distinct. The Jordan Baladi and the Pakistani were closer to each other than the Brahma. Plumage colors were observed either as single color or mottled (a mix of many colors). The latter was the most predominant (23.1\%) followed by black (19.5\%) and light brownish $(19.1 \%)$. The single comb type was the most predominant $(80.3 \%)$. Hens of the local chicken reached sexual maturity at about 22-30 weeks of age. The average clutch number was 1-5 per year, with 18-30 eggs per clutch. Each hen laid on average $68.9 \pm 3.3$ eggs per year. The body size of adult females and males was about $1240 \pm 10 \mathrm{~g}$ and $1890 \pm 30 \mathrm{~g}$, respectively. Indiscriminate crossbreeding was taking place frequently. Genetic characterization would complement the phenotypic characterization and should be conducted. This would help to initiate a program for the preservation of genetic diversity in local chickens in Jordan.

\section{Résumé}

Une enquête a été menée au nord de la Jordanie pour caractériser la diversité des poules locales ainsi que leur potentiel de production. Les informations recueillies sur un échantillon de 846 poules adultes portaient entre autres sur les caractéristiques morphologiques, la couleur du plumage et la forme de la crête. Il existe trois principales variétés de poules locales: le Baladi $(67,3 \%)$, le Pakistani (27,7\%) et le Brahma (5\%). La couleur du plumage est soit uniforme soit composite. Les plumages bigarrées $(23,1 \%)$, uniformément noires $(19,5 \%)$ et uniformément brun clair (19,1\%) sont prédominantes. La majorité (80,3\%) des poules ont une seule crête. Les poules locales atteignent leur maturité sexuelle entre 22 et 30 mois d'âge. Le nombre moyen de couvée par an varie entre 1 et 5 et le nombre d'oeufs par couvée entre 18 et 30 . Chaque poule couve en moyenne $68,9 \pm 3,3$ oeufs par an. Le poids moyen de la femelle adulte est de $1240 \pm 10 \mathrm{~g}$ et celui du male adulte de $1890 \pm 30$ g. Des métissages incontrôlés sont fréquents. Une caractérisation génétique est indispensable pour confirmer les résultats de la présente étude et pour l'initiation d'un programme de préservation de la diversité génétique existante entre et dans les races locales de poules en Jordanie.

\section{Resumen}

Se ha llevado a cabo una encuesta en el norte de Jordania para caracterizar la diversidad de las razas de gallinas locales así como su potencial de producción. Las informaciones recogidas sobre una muestra de 846 gallinas adultas comprendían, entre otras, las características morfológicas, el color de las plumas y la forma de la cresta. Existen tres principales razas de gallinas locales: la Baladi $(67,3 \%)$, la Pakistani $(27,7 \%)$ y la Brahma (5\%). El color de la pluma es o bien uniforme o bien compuesto. Predominan los plumajes compuestos con el $23,1 \%$, los negros con el 19,5\% y los marrones 


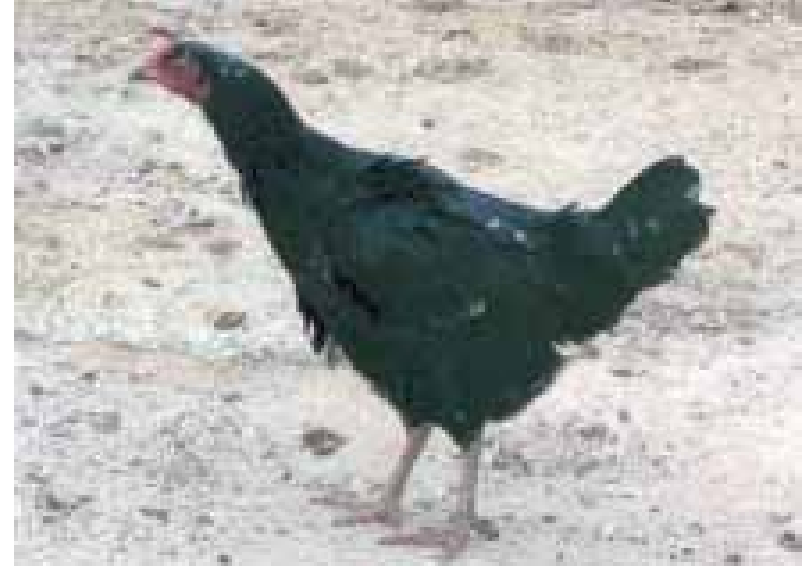

Figure 1a. Black Baladi female.

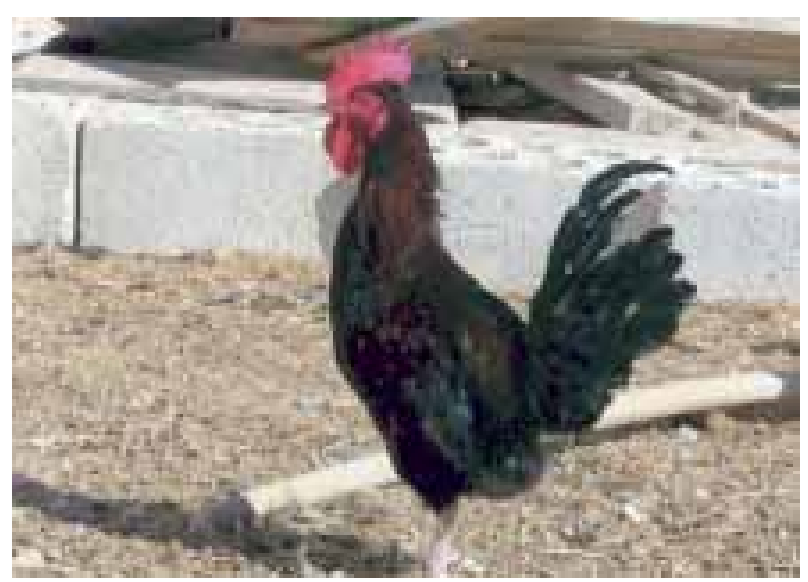

Figure 1b. Baladi male with single comb type.

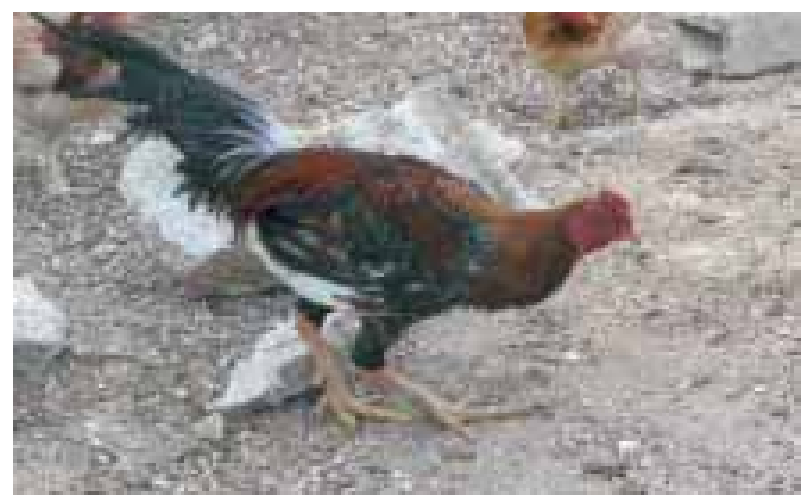

Figure 2. Pakistani male.

claros con el 19,1\%. La mayoría de las gallinas tienen una sola cresta $(80,3 \%)$. Las gallinas de raza local alcanzan la madurez sexual entre los 22 y 30 meses. La media de nidadas por año varía entre 1 y 5 y el número de huevos por nidada entre 18 y 30. Cada gallina incuba una media de
$68,9 \pm 3,3$ huevos por año. El peso medio de la hembra adulta es de 1,240 \pm 10 gr y el del macho adulto de 1,890 $\pm 30 \mathrm{gr}$. Son frecuentes los cruces incontrolados. Es indispensable iniciar una caracterización genética para confirmar los resultados del presente estudio y para poder iniciar un programa de conservación de la diversidad genética existente entre y dentro de la razas locales de gallinas en Jordania.

Keywords: Genetic resources, Jordan, Local chicken, Performance, Phenotype diversity.

\section{Introduction}

'Local chicken' is the general term given to those chickens kept in an extensive system, scavenging free-range, having no identified description, and being dual-purpose and unimproved (Horst, 1989; Pedersen, 2002). Indigenous breeds of chickens are supposed to be more adapted to local environmental conditions and diseases. Horst (1989) considered the indigenous fowl populations a gene reservoir, particularly in respect of those genes that have adaptive values in tropical conditions. One of the important reasons to conserve local chicken genetic resources is to keep genetic variation within and between local breeds. The future improvement and sustainability of local chicken production systems is dependent upon the availability of this genetic variation (Benítez, 2002).

The total chicken population in Jordan was estimated to be 24 million birds of exotic commercial breeds (FAO, 2004b) and one million of local breeds (Abdelqader and Wollny, 2004). The annual per capita consumption of chicken meat and eggs is $22 \mathrm{~kg}$ and $175 \mathrm{eggs}$, respectively (Jordan Ministry of Agriculture, 2005). The local chicken breeds in Jordan are composed of different non-descript types. The production system is small-scale scavenging in a free-range environment. Local chickens constitute a significant portion of human livelihood and contribute significantly to food security (Gondwe, 2004). Local chickens are strictly linked to rural households in Jordan. There is no information available on the diversity among different phenotypes and their approximate performance potential. At present, Jordan has an action plan for the conservation of livestock genetic resources, but this plan is more directed towards small ruminants and imported dairy cattle than toward local poultry breeds (FAO, 2004a). Local chicken populations have been neglected in conservation and development programs. Instead, 
high-input/high-output exotic genotypes were introduced and supported. No studies have been carried out to date to characterize local chickens in Jordan. The objectives of this study were to provide basic information about the diversity of different phenotypes of local chicken and to investigate their productive and reproductive potentials under scavenging conditions.

\section{Materials and Methods}

\section{Study area}

The study was carried out in rural areas of the northern districts of Jordan (Irbid, Ajlun, Jarash, Almfraq). The center of the geographical coordinates is latitudes $32^{\circ} 33^{\prime} \mathrm{N}$ and longitudes $35^{\circ} 50^{\prime} \mathrm{E}$. The area is of Mediterranean climate, characterized by dry, hot summers (June-August) and cold, wet winters (December-February). The rainy season is from November to April. The annual precipitation is approximately $200-350 \mathrm{~mm}$. The average monthly temperature ranges from $5^{\circ} \mathrm{C}$ in January to $32^{\circ} \mathrm{C}$ in August (Jordan Meteorological Department, 2007).

\section{Scope of the study}

The study was conducted to investigate the diversity of different local chicken phenotypes and performance potentials. On-farm studies and surveys were run from October 2004 to February 2005 and from May to July 2005. A total of 120 households selected from 18 villages were included in the study. Data were collected through personal interviews with the head of the family or the caretaker of the chickens.

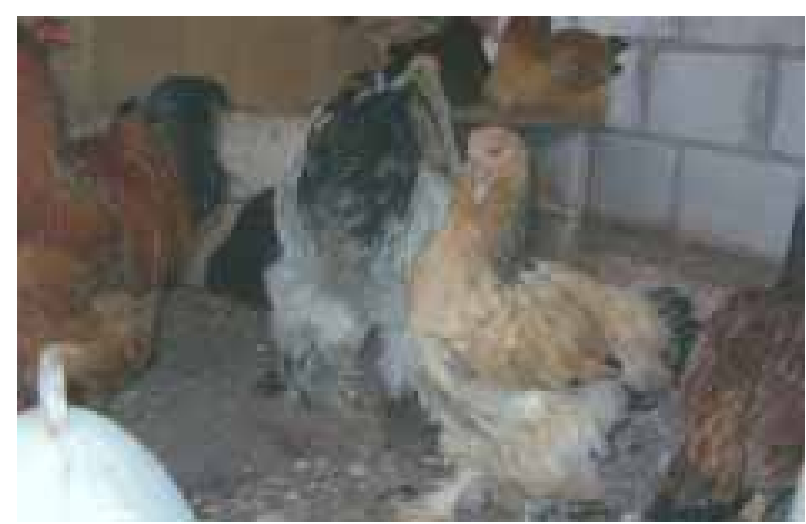

Figure 3. Brahma female with feathered legs.

\section{Data collection}

A sample of 846 adult local chickens was described. General body morphology, feather colors and comb shape were recorded. Farmers were asked about the local names of the different phenotypes, and the criteria they used to distinguish between them. Morphological measurements were recorded on 460 hens of one year old and older for clustering analysis. Ten morphological traits were measured on each hen: body length (BL), neck length (NL), height at thorax (HT), height at hipbone (HB), hip width (HW), withers width (WW), body weight (BW), heart girth (HG), tail slope (TS) and comb shape (CS). Body traits were measured using a measuring tape while the hen was standing upright. The prevalence of other poultry species was also recorded. Performance data were collected through direct observation, measurements and farmer interviews. The annual egg production was estimated by counting the number of clutches per hen per year and the number of laid eggs per clutch. Data relating to body weight and egg weight were taken by direct measurement. Adult males and females were weighed using a hanging type scale, Salter Model 12.

\section{Statistical analysis}

SAS-program version 8 (SAS, 1999) was used for all statistical analysis. PROC FREQ procedure was used to calculate the frequency of different phenotypes within local chickens. PROC MEANS procedure was used for the descriptive statistics of performance data. Before clustering analysis, data were standardized to zero mean and a unit standard deviation because of different units of measurements. Stepwise discriminant procedure was applied to determine which morphological traits would be used in the final clustering analysis; this procedure determines the variables that have more discriminant power than the others. The CANDISC procedure was used to perform uni- and multivariate analyses to derive canonical functions, and to show the clustering among these three types. PROC CLUSTER procedure was used to find out the degree of morphological variations between the clusters. Mahalanobis distances were generated during the canonical discriminate analysis to perform cluster analysis. These distances were used to construct a dendrogram using the unweighted pairs group method analysis. 


\section{Results}

\section{Phenotype diversity and morphological description}

Besides chickens, other poultry species were kept by households. Chickens prevailed over all other poultry species ( $92 \%$ of the poultry population). Pigeons were the second most prevalent species after chickens (5\%), followed by guinea fowl (2\%) and other poultry species (1\%). Farmers get their stocks of chicken either by buying birds from the market, or by hatching eggs by natural brooding or in small artificial hatcheries.

The results showed that the local chicken populations in Jordan are composed of different non-descript types such as the Jordan Baladi (Figures $1 \mathrm{a}$ and $1 \mathrm{~b}$ ) which was the most predominant type (Table 1), followed by the Pakistani (Figure 2) and Brahma (Figure 3). These three types were kept in the same system under the same conditions; therefore they were classified generally under one common name as local. Jordan Baladi is the indigenous type which has cohabited with people since time immemorial. They have horizontal body position and large vertical tail. They are characterized by a smaller body size when compared to he Pakistani and Brahma. Pakistani chickens are supposed to have been introduced to Jordan by the Pakistani communities. This type has larger body size than the Jordan Baladi and an upright stance. Their tail slope tends to be horizontal rather than vertical. They have soft and long feathers, prominent shoulders, a narrow stern and long neck (Figure 2). The Brahma is very similar to the Asiatic breed known as the 'Brahma' and is supposed to have been introduced either by traders or hobbyists. This type has a very large body size and heavy bone and muscles. Birds are highly feathered with feathered legs and toes (Figure 3). Cluster analysis showed that the three types were characterized as three distinct clusters. The Jordan Baladi and the Pakistani were closer to each other than to the Brahma. Measurements that were best able to separate the populations, as judged from stepwise discriminant analysis were: BW, TS, BL, $\mathrm{HG}$ and HB. Mahalanobis distances estimated between the three types are presented in table 2 . The distances between all pair-wise were significant $(P<0.0001)$. The largest distance was between the the Jordan Baladi and Brahma while Pakistani was the closest to the Jordan Baladi. The dendrogram (Figure 4) shows two closer clusters; Jordan Baladi and Pakistani, joined by the Brahma which was significantly separated from the others.

Table 1. Distribution of different phenotypes among 846 adult local chickens in the study area.

\begin{tabular}{|c|c|c|c|}
\hline Item & Phenotype & Number & Per cent \\
\hline \multirow[t]{6}{*}{ Morphology } & Normal & 741 & $(87.6)$ \\
\hline & Naked neck & 8 & $(0.9)$ \\
\hline & Feathered leg & 64 & $(7.6)$ \\
\hline & Frizzled & 5 & $(0.6)$ \\
\hline & Dwarf & 17 & $(2.0)$ \\
\hline & Tail less & 11 & $(1.3)$ \\
\hline \multirow[t]{8}{*}{ Feather color } & Mottled (many colors) & 195 & $(23.1)$ \\
\hline & Black & 165 & $(19.5)$ \\
\hline & Light brownish & 162 & $(19.1)$ \\
\hline & Brown and black & 144 & $(17.0)$ \\
\hline & White & 69 & $(8.2)$ \\
\hline & Spotted with black and white & 60 & $(7.1)$ \\
\hline & Grey & 33 & $(3.9)$ \\
\hline & Black and white & 18 & $(2.1)$ \\
\hline \multirow[t]{3}{*}{ Origin } & Baladi & 570 & (67.3) \\
\hline & Pakistani & 234 & $(27.7)$ \\
\hline & Brahma & 42 & $(5.0)$ \\
\hline \multirow[t]{5}{*}{ Comb type } & Single & 679 & $(80.3)$ \\
\hline & Buttercup & 73 & $(8.6)$ \\
\hline & Double & 42 & $(5.0)$ \\
\hline & Pea & 32 & $(3.8)$ \\
\hline & V-shaped with feathered cap & 20 & $(2.3)$ \\
\hline
\end{tabular}


Table 2. Mahalanobis distance between local chicken types in Jordan based on morpho-structural variables.

\begin{tabular}{lccc}
\hline Type & Jordan Baladi & Brahma & Pakistan \\
\hline Baladi & 0.00 & & - \\
Brahma & 76.88 & 0.00 & - \\
Pakistan & 9.91 & 48.75 & 0 \\
\hline
\end{tabular}

Table 3. Means $( \pm S D)$ of productive and reproductive parameters of local chicken in Jordan.

\begin{tabular}{lcccc}
\hline Performance parameter & Mean & SD & Minimum & Maximum \\
\hline Number of clutches per year & 2.64 & 0.13 & 1 & 5 \\
Egg production per hen per year & 68.90 & 3.31 & 18 & 130 \\
Ag at first lay (week) & 25.80 & 0.17 & 22 & 30 \\
Female body weight (g) & 1240 & 10.00 & 900 & 1700 \\
Male body weight (g) & 1890 & 30.00 & 1100 & 2600 \\
Egg weight (g) & 47.90 & 0.66 & 32.0 & 60.0 \\
\hline
\end{tabular}

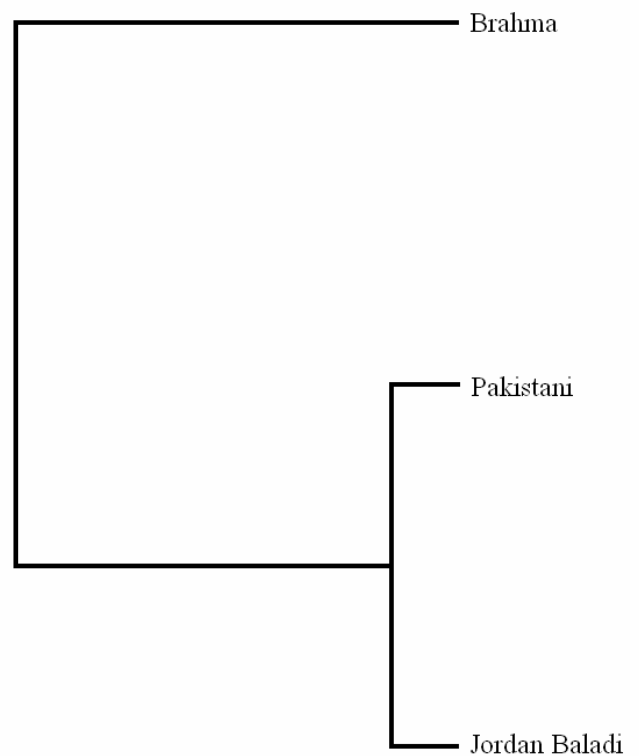

\begin{tabular}{lcccc}
\hline 80 & 60 & 40 & 20 & 0 \\
& Average distance between clusters
\end{tabular}

Figure 4. Dendrogram showing relationship among local chicken populations in Jordan.
Other distinctive phenotypes like Naked Neck (Figure 5), Frizzled (Figure 6) and Tailless (Figure 7) were found in small numbers. Table 1 shows the phenotypic characterization of the local chicken in Jordan. Local chickens were highly heterogeneous in feather color (Figure 8). The most predominant plumage was the mottled feather (mixed colors of plumage, including black, white, brown, red, spangled green, yellow, etc.) followed by black and light brownish. Many comb variants were found, the most frequent comb shape was the single type (Figure 1b) other types like Buttercup (Figure 9) and V-shape with feathered cap (Figure 10) were recognized in different proportions (Table 1).

\section{Productive and reproductive performance}

Means of productive and reproductive parameters of local chicken in Jordan are summarized in table 3. All farmers kept their chickens under free-range conditions where inputs are limited. However, there were wide variations in productive and reproductive potential. Numbers of clutches ranged between 1-5 per year with 18-30 eggs per clutch. However, not all hens become broody and a small number of hens were observed to have continuous egg laying throughout the year. There was a wide range of variability in body size of the birds. Adult females ranged in live body weight from 900 to $1700 \mathrm{~g}$ and similarly males ranged from 1100 to $2600 \mathrm{~g}$. 


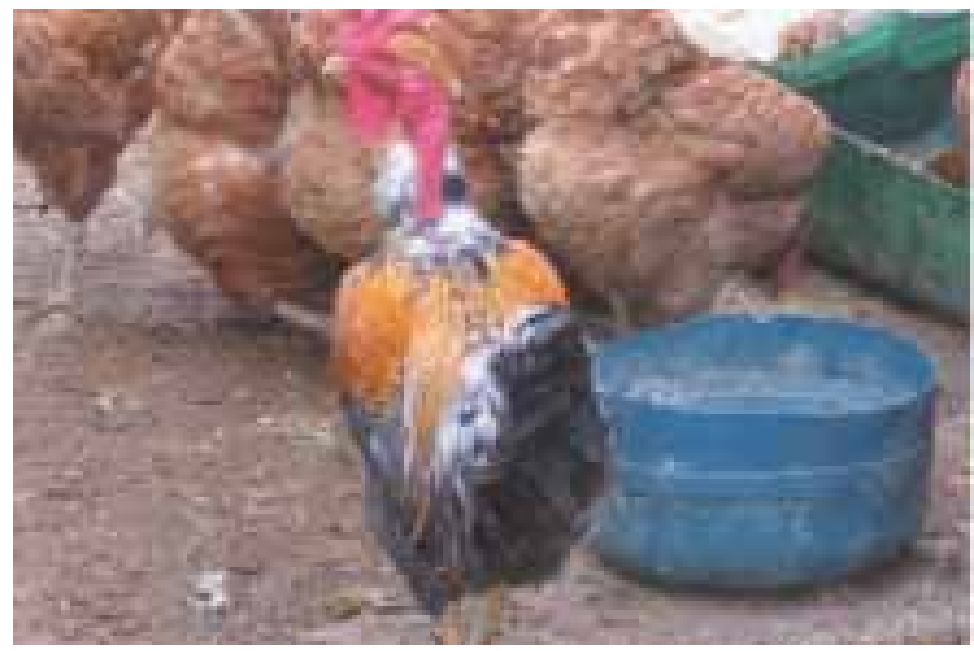

Figure 5. Naked neck male.

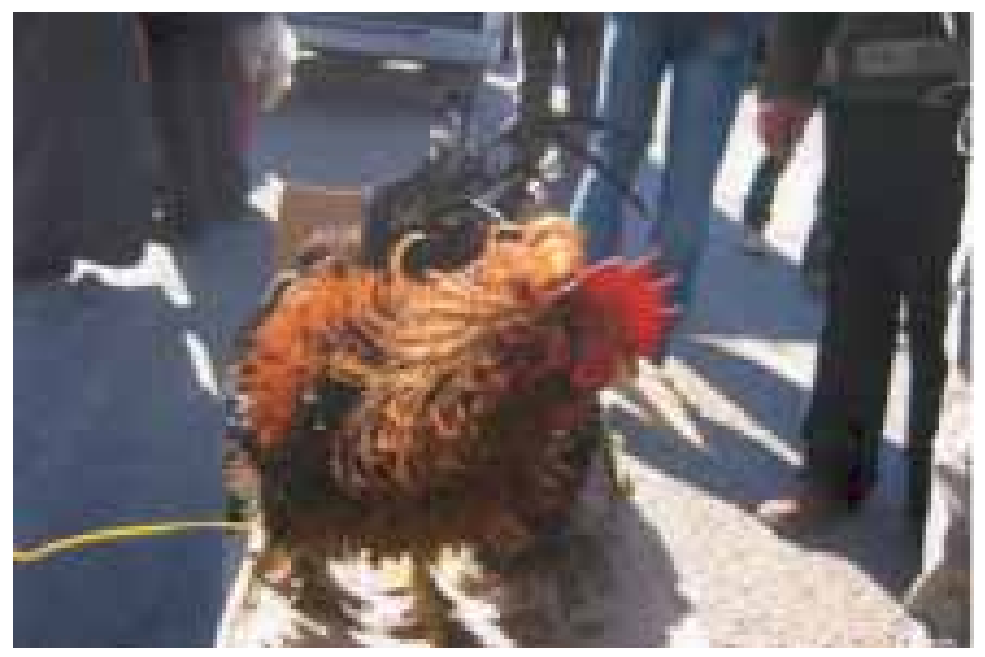

Figure 6. Frizzled male for marketing.

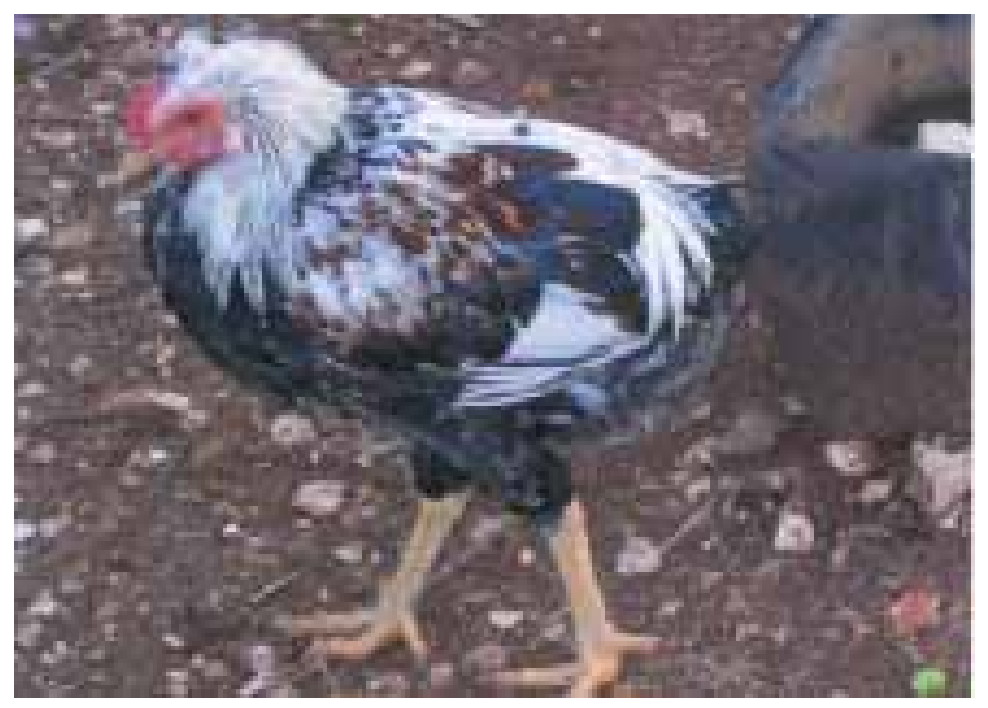

Figure 7. Tail less bird. 


\section{Discussion}

In the current study, the Baladi chicken was the predominant type, which was easily recognized by farmers. Multivariate discriminant analysis of morphological traits has been successfully used to estimate the genetic variation within and between local breeds (Zaitoun et al., 2005; Herrera et al., 1996; Jordana et al., 1993).

The use of cluster analysis in this study was successful in differentiating the local chicken populations based on morphological traits. The present study showed a considerable genetic variability between the three main types of local chickens in Jordan. Great phenotypic variations seem to be the main characteristic of local chickens throughout the world (Wimmers et al., 2000; Pedersen, 2002). Local chickens in Jordan were highly heterogeneous in appearance and plumage colors. Naked Neck gene and Frizzled phenotypes were occasionally observed. The Naked Neck gene is highly prevalent in Ethiopia and about $50 \%$ of chickens are found to be of this type (Tadelle et al., 2003a) while only $2 \%$ of chickens were found to be Naked Neck in Senegal. There were also wide variations in the productive and reproductive performance of local chicken phenotypes. Wide variations in performance were also reported in the literature (Missohou et al., 1998; Pedersen, 2002; Gondwe, 2004). Considerable variations in egg weight and body size were reported by Minga et al. (1989). Similarly, the high variations in clutch number and size observed in this study were in general agreement with previous findings of Mwalusanya et al. (2002) in Tanzania and Tadelle et al. (2003a) in Ethiopia.

Another report from Ethiopia demonstrated that local chickens had 3-4 clutches per year, with 15-20 eggs per clutch (Dessie and Ogle, 2001). Benabdeljelil and Arfaoui (2001) investigated the performance of native chickens in Morocco. They found that hens produced 2-3 clutches per year with annual an production of about 78 eggs. Age at first lay (age at sexual maturity) in the current study was similar to the range proposed by Gueye (1998), from 24 to 32 weeks; Dessie and Ogle (2001), about 28 weeks; and Gondwe (2004), about 25.5 weeks. Other authors reported a greater maturity age of up to 42 weeks (Mwalusanya et al., 2002; Tadelle et al., 2003b). Male and female body sizes were similar to those found elsewhere (Benabdeljelil and Arfaoui, 2001; Dessie and Ogle, 2001).

The wide variations in local chicken performance are ascribed in this study to many factors, mainly the variations in management

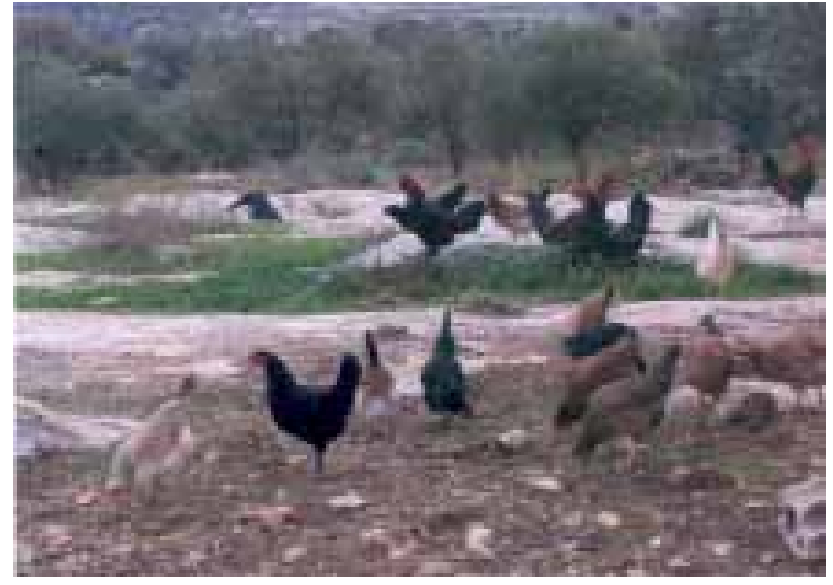

Figure 8. Local chicken with different colored variants.

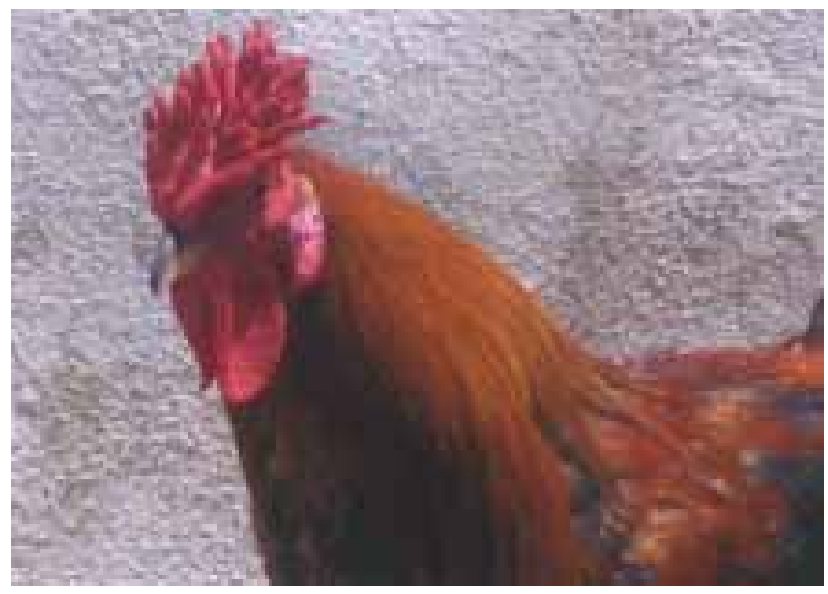

Figure 9. Duplex Buttercup comb shape.

practices between households, the effects of crossbreeding with exotic lines, the availability of scavenging feed resources and feed supplements. Some farmers kept chickens of exotic strains free-roaming together with local chickens. Consequently, indiscriminate crossbreeding occurred. Furthermore, none of the farmers in the study area implement planned crossbreeding in the flock. This will ambiguously affect the frequencies of phenotypes in the population.

Therefore, based on phenotypic assessment, quantitative estimates of the substitution of local genetic material due to uncontrolled crossbreeding were difficult. To assess the impact of crossbreeding and to what extent it was taking place is a very important goal. However, due to the high phenotypic heterogeneity in the local chickens and unplanned crossbreeding, such an approach seems 


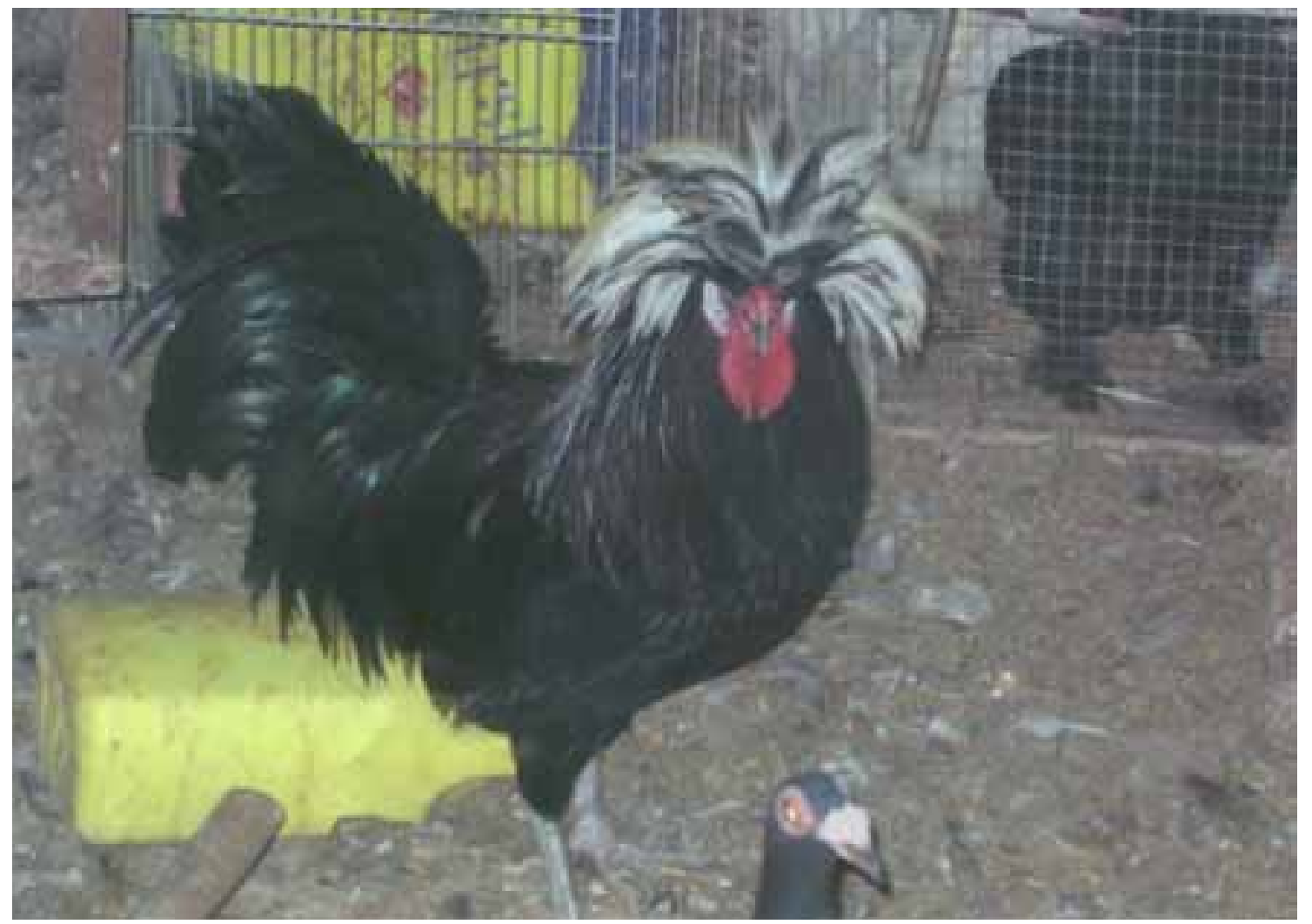

Figure 10. V-shaped comb type with Feather cap.

to be fruitless. The remaining local genetic resources are threatened by improper management, particularly crossbreeding. There is a need to plan a conservation program for local chicken breeds. To conceive an objective plan to conserve the local chicken we need to find out the genetic composition of the local breeds and compare it with other populations.

\section{Conclusion}

The Jordan Baladi, Pakistani and Brahma are characterized as distinct types of local chickens in Jordan. Significant morphological variations between the three types were detected. Body weight, tail slope, body length, heart girth and height at hipbone showed the largest discriminatory power. The high diversity in local chicken phenotypes is major evidence of high genetic variability. Further research should investigate the on-farm performance of each type. Genetic characterization based on molecular assessment should be run to evaluate the genetic diversity between and within local chicken types.

\section{Acknowledgments}

The authors would like to thank the participating households. This research was funded by Georg-August University Göttingen.

\section{List of References}

Abdelqader, A. \& C.B.A. Wollny. 2004. Adaptive Traits and Characterization of the Production System of Local Chickens in Jordan. Deutscher Tropentag. <www.tropentag.de/2004/ abstracts/links/Abdelqader_MsiHQmLp.pdf>. Accessed on November 28, 2006

Benabdeljelil, K. \& T. Arfaoui. 2001.

Characterization of Beldi chicken and turkeys in rural poultry flocks of Morocco: Current state and future outlook. Animal Genetic Resources Information 31, 87-95. 
Benítez, Fraga. 2002. Reasons for the use and Conservation of Some Local Genetic Resources in Poultry. $7^{\text {th }}$ World Congress on Genetic Applied to Livestock Production, August 19-23, 2002, Montpellier, France.

Dessie, T. \& B. Ogle. 2001. Village Poultry Production System in the Central Highlands of Ethiopia. Tropical Animal Health and Production $33,521-537$.

FAO. 2004a. Domestic Animal Diversity Information System. FAO, Rome <http://dad.fao.org/ en/refer/library/sow/597.pdf>. Accessed on February 28, 2007.

FAO. 2004b. FAOSTAT Database. FAO, Rome $<$ http://faostat.fao.org/faostat>. Accessed on February 28, 2007.

Gondwe, T.N.P. 2004. Characterization of local chicken in low input-low output production systems: Is there scope for appropriate production and breeding strategies in Malawi? Phd Thesis, Georg-August-Universität Göttingen, Goettingen, Germany.

Gueye, H.F. 1998. Village egg and fowl meat production in Africa. World's Poultry Science Journal 54, 73-86.

Herrera, M., E. Rodero, M.J. Gutierrez, F. Pena \& J.M. Rodero. 1996. Application of multifactorial discriminant analysis in the morphostructural differentiation of Andalusian caprine breeds. Small Ruminant Research. 22, 39-47.

Horst, P. 1989. Native fowl as reservoir for genomes and major genes with direct and indirect effects on the adaptability and their potential for tropically oriented breeding plans. Archiv für Geflügelkunde 53 (3), 93-101.

Jordan Meteorological Department. 2007. $<w w w . j m d . g o v . j o>$. Acessed on February 28, 2007.

Jordan Ministry of Agriculture. 2005. Annual agriculture report. Amman. Jordan.

Jordana, J., O. Ribo \& M. Pelegrin. 1993. Analysis of genetic relationships from morphological characters in Spanish goat breeds. Small Ruminant Research. 12, 301-314.
Minga, U.M., A. M. Katule, T. Maeda \& J. Musasa. 1989. Potential of the traditional chicken industry in Tanzania. In: Proceedings of the $7^{\text {th }}$ Tanzania Veterinary Association Scientific Conference. TVA Vol. 7: 207-215.

Missohou, A., R.S. Sow \&

C. Ngwe-Assoumou. 1998. Caractéristiques morphobiométriques de la poule du Sénégal. Animal Genetic Resources Information Bulletin 24, 63-69.

Mwalusanya, N.A., A.M. Katule, S.K. Mutayoba, M.M.A. Mtambo, J.E. Olsen \& U.M. Minga. 2002. Productivity of Local Chickens under Village Management Conditions. Tropical Animal Health and Production 34, 405-416.

Pedersen, C.V. 2002. Production of semi-scavenging chicken in Zimbabwe. PhD Thesis. Royal Veterinary and Agricultural University, Copenhagen, Denmark.

SAS. 1999. SAS Users Guide, Version 8.1, SAS Institute Inc. Cary, NC, USA.

Tadelle, D., T. Million, Y. Alemu \& K.J. Peters. 2003a. Village chicken production systems in Ethiopia: 1. Flock characteristics and performance. Livestock Research for rural development 15(1). <www.cipav.org.co/cipav/pubs/ index.htm>. Accessed on February 28, 2007.

Tadelle, D., Y. Million Talemu \& K.J. Peters. 2003b. Village chicken production systems in Ethiopia: 2. Use patterns and performance valuation and chicken products and socio-economic functions of chicken. Livestock Research for rural development. 15(1). <http:// www.cipav.org.co/cipav/pubs/index.htm>. Accessed on February 28, 2007,

Wimmers, K., S. Ponsuksili, T. Hardge, A. Valle-Zarate, P.K. Mathur \& P. Horst. 2000. Genetic distinctness of African, Asian and South American local chickens. Animal Genetics 31, 159-165.

Zaitoun, I.S., M.J. Tabbaa \& S. Bdour. 2005. Differentiation of native goat breeds of Jordan on the basis of morphostructural characteristics. Small Ruminant Research. 56, 173-182. 